\title{
Temperature variations in lake ice in central Alaska, USA
}

\author{
Marc GOULD, Martin JEFFRIES \\ Geophysical Institute, University of Alaska Fairbanks, 903 Koyukuk Drive, Fairbanks, AK 99775-7320, USA \\ E-mail: marc.gould@gi.alaska.edu
}

\begin{abstract}
In winter 2002/03 and 2003/04, thermistors were installed in the ice on two shallow ponds in central Alaska, USA, in order to obtain data on ice temperatures and their response to increasing and decreasing air temperatures, and flooding and snow-ice formation. Snow depth and density, and ice thickness were also measured in order to understand how they affected and were affected by ice temperature variability. The lowest ice temperature $\left(-15.5^{\circ} \mathrm{C}\right)$ and steepest temperature gradient $\left(-39.8^{\circ} \mathrm{C} \mathrm{m}^{-1}\right)$ occurred during a 9 week period in autumn $2002 / 03$ when there was no snow on the ice. With snow on the ice, temperature gradients were more typically in the range $\mathbf{- 2 0}$ to $-5^{\circ} \mathrm{C} \mathrm{m}^{-1}$. Average ice temperatures were lower during the warmer, first winter, and higher during the cooler, second winter because of differences in the depth and duration of the snow cover. Isothermal ice near the freezing point resulted from flooding and snow-ice formation, and brief episodes of warm weather with freezing rain. Under these circumstances, congelation-ice growth at the bottom of the ice cover was interrupted, even reversed. It is suggested that the patterns in temperatures brought about by the snow-ice formation and rain events may become more prevalent due to the increase in frequency of these events in central Alaska if temperature and precipitation change as predicted by Arctic climate models.
\end{abstract}

\section{INTRODUCTION}

The thickening of lake ice and the type of ice growth are primarily a function of the combined, and sometimes competing, effects of air temperature and snow on the ice. Since the thermal conductivity of snow is 1-2 orders of magnitude lower than that of ice, it provides significant thermal resistance that affects the ice thermal regime and the rate of congelation-ice growth at the bottom of the ice cover. On the other hand, the thickening of ice by snow-ice formation at the ice surface is initially independent of the thermal resistance of the snow and the ice thermal regime. Snow-ice formation is initiated when the mass of snow on the ice causes the ice to sink below the pond's water level and water flows up through fractures to the ice surface. Only then does the thermal resistance of the snow become a factor in freezing the slush into snow ice.

The formation, thickness and thermal regime of sea ice have been the subject of a number of studies (e.g. Lytle and Ackley, 1996; Perovich and Elder, 2001). There have been numerous studies of the formation and thickness of lake ice (e.g. Jones, 1969; Gow and Langston, 1977; Adams and Roulet, 1980; Adams and Prowse, 1981; Bengtsson, 1986), but the thermal regime and its response to air-temperature variability, snow accumulation and ice formation have received little attention. A study of ice formation and thickness on shallow $(2-3 \mathrm{~m})$ ponds in the vicinity of Poker Flat Research Range (PFRR), central Alaska, USA, also included ice temperature measurements. In this paper, we describe the temperature field in the ice at two ponds during the course of the growth season, with a particular focus on the response to flooding and snow-ice formation events, and air-temperature decreases and increases. Some of the latter coincided with freezing rain.

\section{STUDY AREA AND METHODS}

Ice temperatures and snow and ice properties were measured between October and April 2002/03 and 2003/04 at
MST pond $\left(65.13^{\circ} \mathrm{N}, 147.45^{\circ} \mathrm{W}\right)$ and 33.5 mile pond $\left(65.15^{\circ} \mathrm{N}, 147.38^{\circ} \mathrm{W}\right)$ in the Chatanika River valley $35 \mathrm{~km}$ northeast of Fairbanks, Alaska. Here we present data for 33.5 mile pond in 2002/03 and MST pond in 2003/04. The MST pond data for 2002/03 are not significantly different than the 33.5 mile pond data that winter. A flooding event in late November 2003 at 33.5 mile pond damaged the datalogger, and no further data were obtained. A concurrent flooding event at MST pond is described later in this paper. Data on ice-thickness increases due to flooding and snowice formation in November 2003 at 31.6 mile pond $\left(65.14^{\circ} \mathrm{N}, 147.44^{\circ} \mathrm{W}\right)$ are also presented.

Temperatures were measured with thermistor strings that extended from the air through the snow and ice into the water. They were installed at the center of each pond when the ice was $24 \mathrm{~cm}$ thick (9 November 2002) at 33.5 mile pond, and $15 \mathrm{~cm}$ thick (24 October 2003) at MST pond. The strings were composed of Omega 44031 thermistors which are calibrated and uniform to $0.1^{\circ} \mathrm{C}$, but their potential resolution is close to $0.001^{\circ} \mathrm{C}$. They were spaced

1. $2.5 \mathrm{~cm}$ apart to a height of $15 \mathrm{~cm}$, and at 20, 30 and $40 \mathrm{~cm}$ above the ice surface, where snow-ice formation would occur, and

\section{2. $5 \mathrm{~cm}$ apart to $1 \mathrm{~m}$ depth below the ice surface.}

All ice depths and temperatures are referenced to this original surface, i.e. $0 \mathrm{~cm}$. Temperatures were recorded on the hour, Alaska Daylight Saving Time (ADST, -0800 UTC), with Campbell CR10X dataloggers. Measurements ceased in spring, when the melting ice could no longer hold the thermistor strings in place.

In the early stages of ice growth, when it was not safe to walk on the ice, snow depth and ice thickness were measured 3-4 times per week at the edge of each pond. Subsequently, heated wire gauges (nine at MST pond, three at 33.5 mile pond) were used to measure the ice thickness (accuracy $0.5 \mathrm{~cm}$ ) and change in height of the ice surface, 


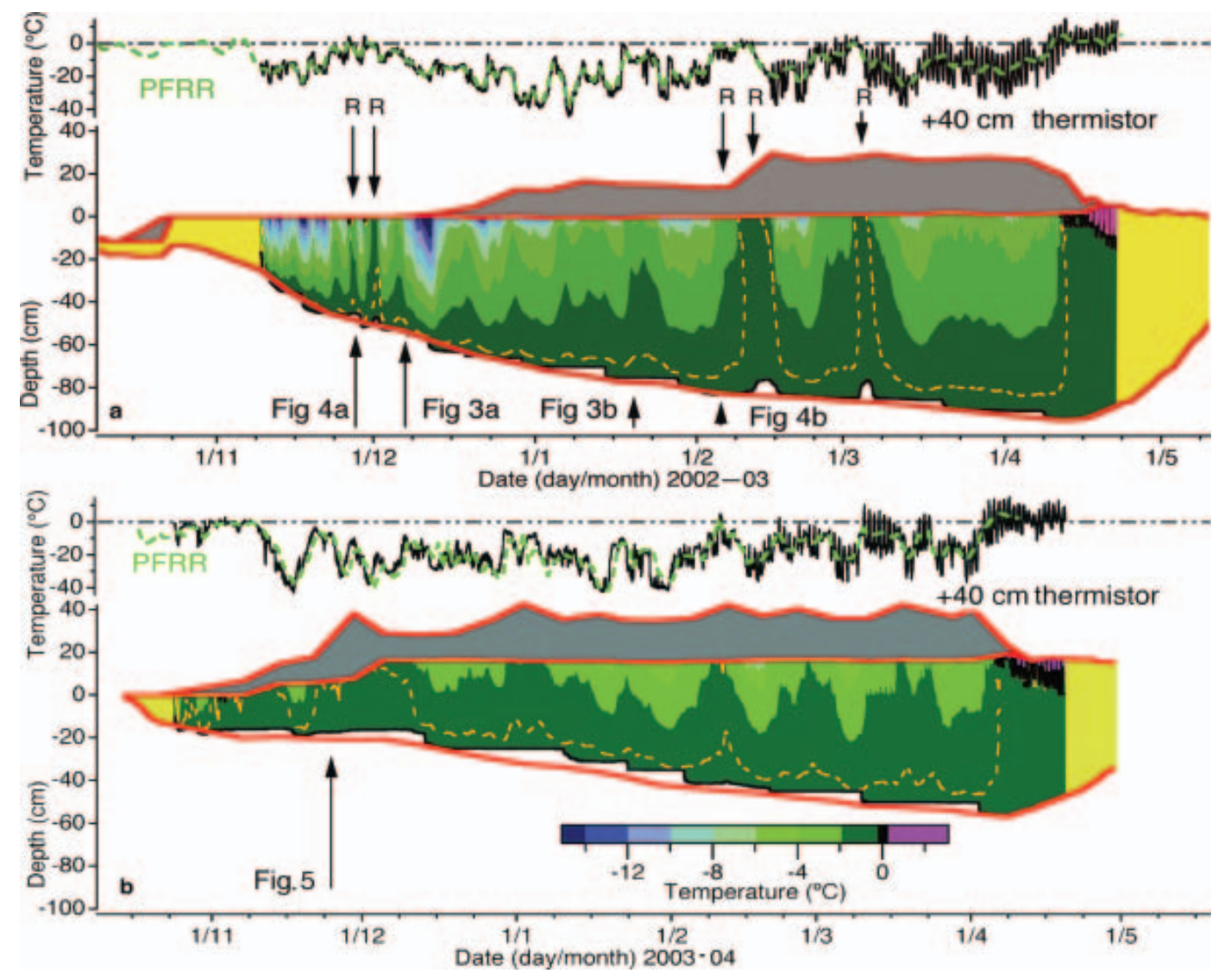

Fig. 1. Ice temperature fields at (a) 33.5 mile pond in winter 2002/03 and (b) MST pond in winter 2003/04. The mean daily air-temperature records at the top of (a) and (b) are from the thermistor located $40 \mathrm{~cm}$ above the original ice surface (black) and from PFRR (green), $1.5 \mathrm{~km}$ west of MST pond and $4 \mathrm{~km}$ west of 33.5 mile pond. Snow on the ice is represented in grey. Yellow represents periods when no ice temperatures were recorded but ice thickness was measured. Red lines represent the top of the snow cover, and the top and bottom of the ice. The stepped black line is the $0^{\circ} \mathrm{C}$ isotherm. The dashed line is the $-0.5^{\circ} \mathrm{C}$ isotherm. Downward-pointing arrows marked $\mathrm{R}$ identify rainfall events. Upward-pointing arrows marked Fig. identify examples, described in detail in the text, of the effects on ice temperatures of increasing and decreasing air temperatures, and flooding and snow-ice formation. Depth is measured from the ice surface at the time of thermistor installation.

and thus snow-ice accretion (Ramseier and Weaver, 1975). Mean snow depth (accuracy $0.1 \mathrm{~cm}$ ) on the ice was determined from measurements at the ice gauges. Mean snow density (accuracy $1 \mathrm{~kg} \mathrm{~m}^{-3}$ ) was determined from snow samples (seven at MST pond, three at 33.5 mile pond) obtained along transects extending across the ice cover. Snow depth and density, and ice thickness were measured once per week during the ice-growth season, and 3-4 times per week during the snowmelt season. Once the snow had melted completely, ice thickness was measured as often as once per day until it was no longer safe to be on the ice.

\section{RESULTS}

\subsection{Air temperature, snow depth and ice thickness}

Winter 2002/03 was warmer than winter 2003/04, as indicated by the mean and variance of air temperatures, and the number of freezing degree-days (Table 1). Air temperature fluctuated considerably and periods of extremely cold weather $\left(<-20^{\circ} \mathrm{C}\right)$ lasted only $2-3$ days each winter (Fig. 1$)$. Air temperatures $>0^{\circ} \mathrm{C}$ occurred occasionally, and in 2002/ 03 some of these warm intervals included rain (Fig. 1a).

There was snow on the ice almost throughout winter 2003/04 at MST pond (Fig. 1b), whereas in 2002/03 the ice

Table 1. Summary of air temperature, freezing degree-days and ice thickness and type at MST and 33.5 mile ponds

\begin{tabular}{|c|c|c|c|c|c|c|c|}
\hline & \multicolumn{3}{|c|}{ Daily means } & \multirow[t]{3}{*}{ Freezing degree-days } & \multicolumn{3}{|c|}{ Max. ice thickness } \\
\hline & Mean & Std dev. & Min. & & Total & Snow ice & Congelation ice \\
\hline & ${ }^{\circ} \mathrm{C}$ & ${ }^{\circ} \mathrm{C}$ & ${ }^{\circ} \mathrm{C}$ & & $\mathrm{cm}$ & $\mathrm{cm}$ & $\mathrm{cm}$ \\
\hline $33.5(2002 / 03)$ & -11.9 & 8.5 & -36.22 & 2063 & 97.4 & 14.6 & 82.8 \\
\hline MST $(2003 / 04)$ & -15.6 & 10.4 & -41.56 & 2746 & 76.1 & 19.2 & 57.0 \\
\hline
\end{tabular}

Note: The mean temperature and freezing degree-day values represent the period 16 October-8 April each year. 


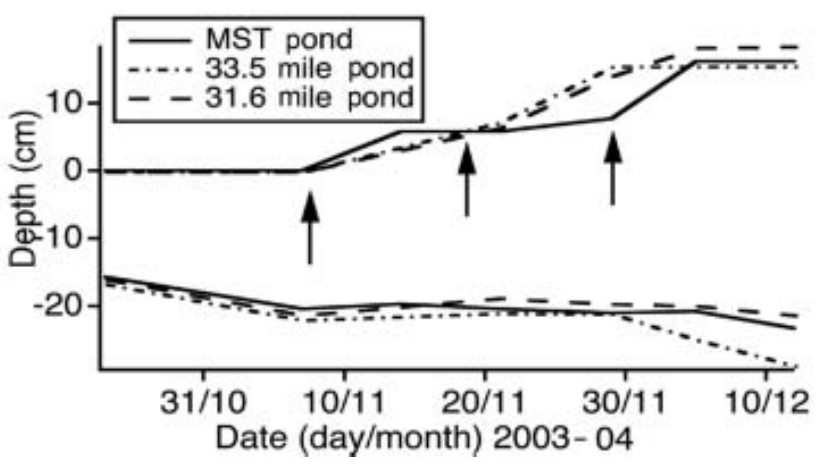

Fig. 2. Ice-thickness change due to flooding and snow-ice formation events between early November and mid-December 2003 at MST, 31.6 mile and 33.5 mile ponds. The arrows indicate the onset of icethickness increase due to the accretion of snow ice at MST pond.

at 33.5 mile pond was bare between mid-October and midDecember (Fig. 1a). This prolonged period of bare ice was due to flooding and conversion of the entire snow cover into snow ice in mid-October 2002 (Fig. 1a). Only from late February to mid-April 2003 was the snow at 33.5 mile pond deeper than at MST pond, and then by only a few centimeters (Fig. 1).

Between early November and early December 2003, three flooding and snow-ice formation events led to rapid thickening of the ice cover (Fig. 2). Concurrently, there was negligible bottom accretion of congelation ice. Indeed, the ice-thickness data indicate that bottom melting occurred as the ice surface was flooded and snow ice formed (Fig. 2). By 12 December 2003, the ice cover at MST and 33.5 mile ponds was composed of $>40 \%$ snow ice, and at the time of maximum ice thickness in April 2004 it was composed of $25 \%$ snow ice (Table 1 ). At the time of maximum ice thickness in April 2003 the ice at 33.5 mile pond was composed of $15 \%$ snow ice (Table 1 ).

Although winter 2002/03 was warmer than winter 2003/04, the ice was thicker in 2002/03 (Fig. 1a). Maximum ice thicknesses of $97 \mathrm{~cm}$ on 18 April 2003 and $91 \mathrm{~cm}$ on 12 April 2003 occurred at 33.5 mile and MST ponds, respectively. Maximum ice thicknesses of 77 and $76 \mathrm{~cm}$ on 8 April 2004 occurred at 33.5 mile and MST ponds, respectively.

The mean dry-snow density at MST and 33.5 mile ponds was $157 \pm 26$ and $142 \pm 28 \mathrm{~kg} \mathrm{~m}^{-3}$, respectively, corresponding to thermal conductivity values of 0.059 and $0.056 \mathrm{~W} \mathrm{~m}^{-1} \mathrm{~K}^{-1}$, respectively (Sturm and others, 1997). Consequently, the thermal resistance of the snow on the ice was mainly a function of its depth and temperature. The ice-thickness difference between 2002/03 and 2003/04 can be attributed to more negative temperature gradients in $2002 / 03$. The longer-duration and generally deeper snow cover of 2003/04 provided greater thermal resistance and thus reduced the contribution of congelation-ice growth to the total ice thickness compared to 2002/03.

\subsection{Ice temperature}

\subsubsection{Ice temperature fields}

Because the snow cover was thinner and had lower thermal resistance in 2002/03, the ice was colder than in winter 2003/04 (Fig. 1). As one would expect, the lowest ice temperatures occurred for a prolonged period during autumn 2002 when there was no snow on the ice
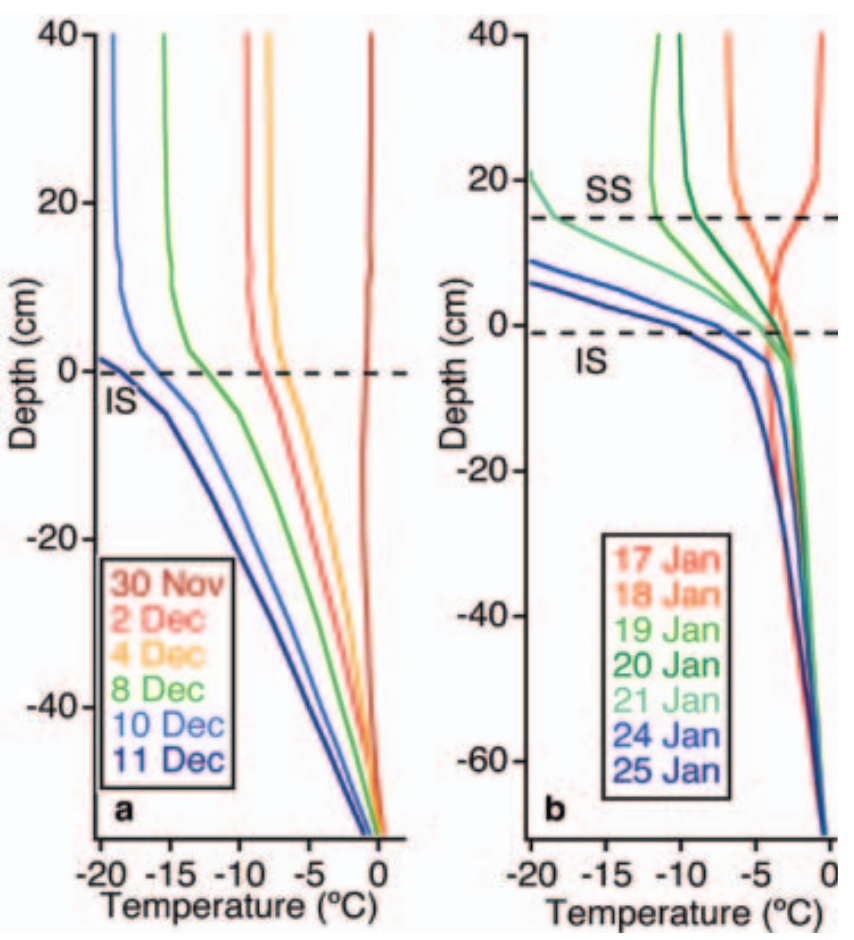

Fig. 3. Temperature profiles in ice, snow and air at 33.5 mile pond during periods of decreasing air temperature, (a) 30 November11 December 2002 and (b) 17-25 January 2003. SS and IS are snow surface and ice surface, respectively. Depth is measured from the ice surface at the time of thermistor installation.

(Fig. 1a). Also during this time, air-temperature decreases and increases had an almost immediate effect on almost the entire ice thickness. Once there was a snow cover on the ice, the upper $\sim 50 \%$ of the ice cover showed the most rapid response to decreasing air temperatures. On the other hand, the entire ice cover responded rapidly to air-temperature increases and flooding events that left the ice isothermal close to its freezing point. Because of the warming events, the ice temperature field is rather different from that in Arctic sea ice, where the lowermost layers of the ice progressively cool as a cold front propagates down through the ice during the winter (Perovich and Elder, 2001). A downwardpropagating cold front is not apparent in the lake ice (Fig. 1). In the next two sections, we describe in more detail the effects on temperatures in bare and snow-covered ice of increasing and decreasing air temperatures, and the effects on ice temperatures of flooding and snow-ice formation. To illustrate the effects of air-temperature increases we have chosen extreme events that included rainfall.

\subsubsection{Ice temperature response to decreasing and increasing air temperature}

Temperature profiles in bare ice as air temperatures decreased in early December 2002 are illustrated in Figure 3a. Initially, on 30 November, the ice was isothermal at the freezing point after a period of warm weather when air temperatures were briefly $>0^{\circ} \mathrm{C}$ (Fig. 1a). During the next 12 days, as mean daily air temperature decreased from $+1.3^{\circ} \mathrm{C}$ to $-20.0^{\circ} \mathrm{C}$, ice temperatures decreased and a linear temperature gradient was maintained between $-5 \mathrm{~cm}$ and the bottom of the ice as the total ice thickness increased from $50 \mathrm{~cm}$ to $60 \mathrm{~cm}$. From 2 to 11 December, the temperature gradient across that thickness of ice steepened 

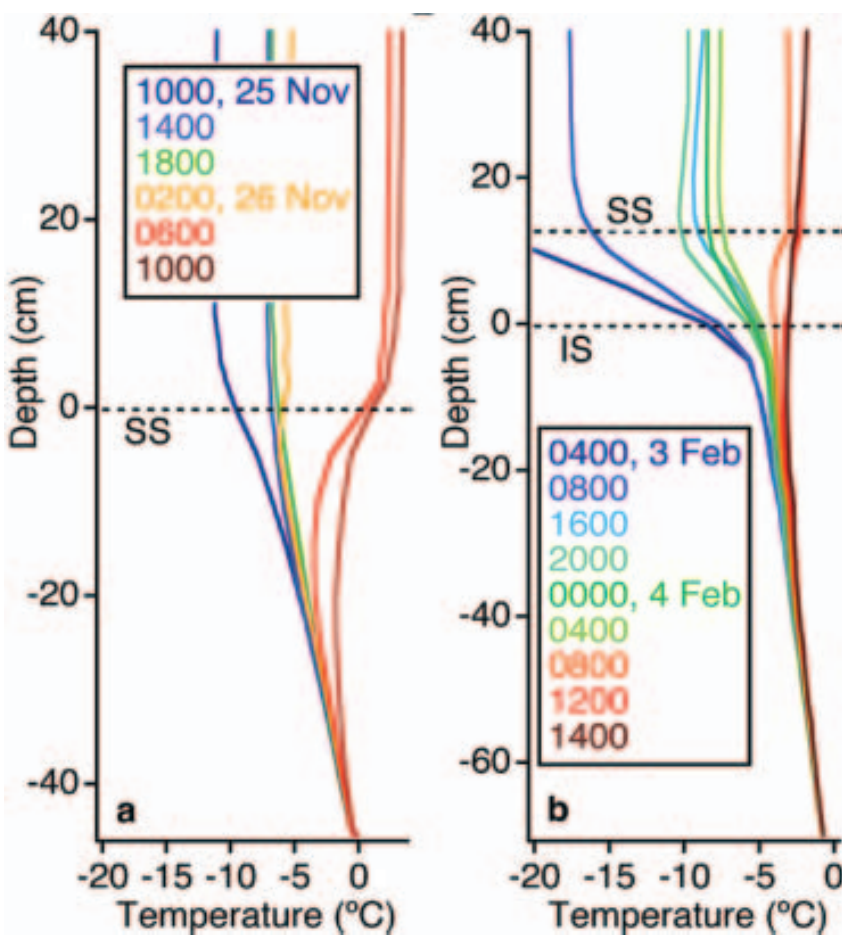

Fig. 4. Temperature profiles in ice, snow and air during periods of increasing air temperature, (a) 25-26 November 2002 and (b) 3-4 February 2003, at 33.5 mile pond. SS and IS are snow surface and ice surface, respectively. All profiles in (a) are at $2000 \mathrm{~h}$ and in (b) are at $1900 \mathrm{~h}$. Depth is measured from the ice surface at the time of thermistor installation.

from $-4.6^{\circ} \mathrm{C} \mathrm{m}^{-1}$ to $-25.2^{\circ} \mathrm{C} \mathrm{m}^{-1}$. The lowest ice temperature $\left(-15.5^{\circ} \mathrm{C}\right)$ recorded during either winter occurred at $-5 \mathrm{~cm}$ depth at $2200 \mathrm{~h}$ on 11 December. At $0900 \mathrm{~h}$ on 12 December, 13 days after air temperatures began to fall, the ice stopped cooling. Ice temperature then began to increase in response to increasing air temperatures.

Temperature profiles in ice with a $17 \mathrm{~cm}$ deep snow cover and decreasing air temperatures in January 2003 are illustrated in Figure 3b. Initially, on 17 January, the ice was almost isothermal at the freezing point. During the next 8 days, as mean daily air temperature decreased from $-16.5^{\circ} \mathrm{C}$ to $-26.2^{\circ} \mathrm{C}$, there was a small decrease in ice temperatures, and the development of a modestly negative temperature gradient (Fig. 3b). On 25 January, when air temperatures stopped falling, the linear temperature gradient between -10 and $-70 \mathrm{~cm}$ was $-7.7^{\circ} \mathrm{Cm}^{-1}$. At $0100 \mathrm{~h}$ on 31 January, 13 days after air temperatures began to fall, the ice stopped cooling.

Temperature profiles in bare ice as air temperatures increased and freezing rain occurred during 25-26 November 2002 are illustrated in Figure 4a. Initially, at $1000 \mathrm{~h}$ on 25 November, when the air temperature was $-12.0^{\circ} \mathrm{C}$, the temperature gradient between -5 and $-45 \mathrm{~cm}$ was $-20.9^{\circ} \mathrm{C} \mathrm{m}^{-1}$ and the temperature at $-5 \mathrm{~cm}$ was $-7.9^{\circ} \mathrm{C}$. Over the next 24 hours, as freezing rain occurred around $0600 \mathrm{~h}$ and air temperatures increased rapidly to $+3.2^{\circ} \mathrm{C}$ at $1000 \mathrm{~h}$ on 26 November, ice temperatures increased and the negative temperature gradient in the uppermost $20 \mathrm{~cm}$ of ice was reversed. In the topmost $5 \mathrm{~cm}$ of ice, the temperature gradient changed from $-39.8^{\circ} \mathrm{C} \mathrm{m}^{-1}$ (1000 h, 25 November) to $+33.8^{\circ} \mathrm{C} \mathrm{m}^{-1}(1000 \mathrm{~h}, 26$ November). During the same 24 hour period, a negative temperature gradient was maintained between -20 and $-45 \mathrm{~cm}$, but it became much less steep, from $-16.1^{\circ} \mathrm{Cm}^{-1}(1000 \mathrm{~h}, 25$ November) to $-6.5^{\circ} \mathrm{Cm}^{-1}$ (1000 h, 26 November).

Temperature profiles are illustrated in Figure $4 \mathrm{~b}$ for ice with a $13 \mathrm{~cm}$ deep snow cover as air temperature increased and freezing rain occurred during 3-4 February 2003. Precipitation occurred during the afternoon and early evening of 3 February. Prior to the onset of precipitation, the air temperature was $-23.1^{\circ} \mathrm{C}$ and the ice was moderately cold, with a snow/ice interface temperature of $-8.5^{\circ} \mathrm{C}$ and a $-5 \mathrm{~cm}$ temperature of $-5.7^{\circ} \mathrm{C}$ at $0400 \mathrm{~h}$ on 3 February. Air temperatures increased rapidly during 3 February, remained fairly constant and moderately cold overnight and increased further during the morning of 4 February. Snow and ice temperatures responded quickly to the rapid increase in air temperature and the precipitation (Fig. 4b). By $0800 \mathrm{~h}$ on 4 February, when the air temperature was $-3.1^{\circ} \mathrm{C}$, the snow was isothermal and the ice almost isothermal.

The ice-warming event of 3-4 February 2003 was a precursor to two more extreme ice-warming events, when the ice temperature field was characterized by chimney-like features. These were the result of particularly high air temperatures and long periods of freezing rain in midFebruary and early March (Fig. 1a). The ice temperatures increased rapidly and the ice became isothermal at the freezing point for 104 hours (8-13 February) and 55 hours (2-5 March). Also, snowmelting occurred and $0.5-1.0 \mathrm{~cm}$ thick superimposed-ice layers formed as the percolating meltwater froze at the ice surface. Section 3.2.3 describes the effects of flooding the ice surface from below.

\subsubsection{Ice-temperature response to flooding and snow-ice formation}

As noted in section 3.2.1, on three occasions between early November and early December 2003 the ice surface flooded and the ice thickness increased by the addition of snow ice (Fig. 2). Here, we illustrate ice temperature variability associated with the final flooding event that occurred on 29 November, the freezing of the slush, and the further cooling of the new snow ice and the older ice below. According to the ice temperatures, $5 \mathrm{~cm}$ of slush and snow ice formed at the thermistors. The depth of flooding and snow-ice thickness is not uniform across these ponds, and measurements made at the ice gauges on 5 December showed that an average of $9 \mathrm{~cm}$ of snow ice had formed.

Prior to the flooding event, air temperatures had been quite high $\left(>-5.0^{\circ} \mathrm{C}\right)$ and the ice was warm. The temperature profile in the topmost layer of ice at $0600 \mathrm{~h}$ on 29 November (Fig. 5a) was typical of the previous 6 hours. At $0600 \mathrm{~h}$, the snow/ice interface temperature was $-0.9^{\circ} \mathrm{C}$, and the temperature gradient in the topmost $5 \mathrm{~cm}$ of ice was moderately negative $\left(-5.6^{\circ} \mathrm{Cm}^{-1}\right)$. Five hours later, the lowermost $5 \mathrm{~cm}$ of the snow cover was totally flooded, the temperature of the slush was as high as $+0.4^{\circ} \mathrm{C}$ and the topmost $7.5 \mathrm{~cm}$ of ice was isothermal at $-0.3^{\circ} \mathrm{C}$ (Fig. $5 \mathrm{a}$ and $\mathrm{c}$ ).

Snow temperatures remained below $0^{\circ} \mathrm{C}$ and snow temperature gradients remained negative after the flooding event (Fig. 5a and b). The slush was freezing by $1800 \mathrm{~h}$ on 30 November, 17 hours after flooding had ceased. It then took 22 hours for the slush to freeze completely and a layer of snow ice to be added at the top of the ice cover (Fig. 5b). At the time (1600 h, 1 December) the slush had completely frozen, but the temperature gradient in the snow-ice layer 


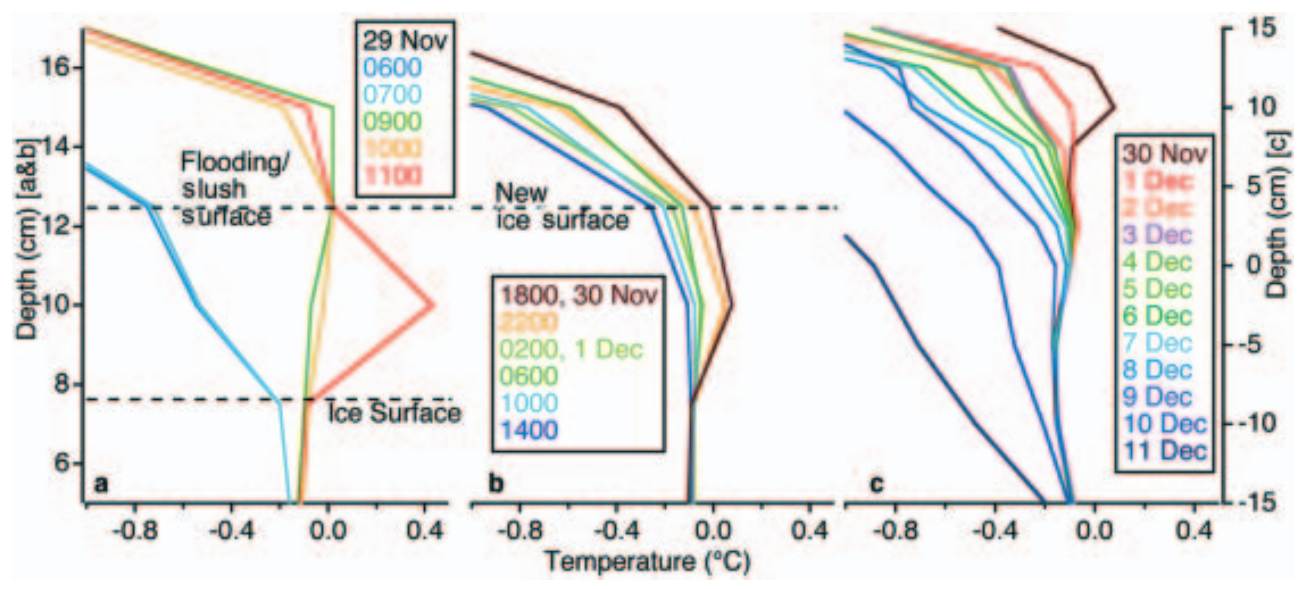

Fig. 5. Temperature profiles in snow, slush and ice at MST pond when the ice surface flooded and snow ice subsequently formed in late November and early December 2003: (a) flooding event on 29 November; (b) freezing of the slush on 30 November and 1 December; (c) cooling of the ice once the slush layer was completely frozen, 2-10 December. All profiles in (c) are at $1200 \mathrm{~h}$. Depth is measured from the ice surface at the time of thermistor installation.

was not linear (Fig. 5b). A linear temperature gradient of $-3.8^{\circ} \mathrm{C} \mathrm{m}^{-1}$ was established in the new snow-ice layer by $1200 \mathrm{~h}$ on 4 December (Fig. 5c). The underlying ice continued to cool after the flooding and refreezing events, but the magnitude and rate of cooling of these upper ice layers were low (Fig. 5c).

\section{DISCUSSION AND CONCLUSION}

The data represent contrasts that include the growth of a relatively thick ice cover during a warm winter, due to delayed and subsequently moderate snow accumulation, compared to the growth of a relatively thin ice cover during a colder winter, due to a longer-duration, moderately deep snow cover. As a consequence of the greater thermal resistance of the longer-duration, deeper snow cover, the ice was warmer during the colder winter.

The data also represent extremes that include a long period of bare ice in autumn 2002 and five freezing-rain events during 2002/03. The lowest ice temperatures and most negative temperature gradients occurred during the bare-ice period. During the same period, a brief freezingrain event and sharp rise in air temperature caused a rapid increase in ice temperatures and reversal of ice temperature gradients from moderately negative to roughly zero.

While the ice was bare in autumn 2002, ice temperature gradients were very steep, i.e. as much as $-40^{\circ} \mathrm{C} \mathrm{m}^{-1}$. The steep temperature gradients are reflected in the rapid increase of ice thickness at this time by congelation-ice growth at the bottom of the ice cover, when conductive heat flow would have been high. The ice was much warmer in autumn 2003 because of the thermal resistance of the snow cover, compounded by flooding events that further increased ice temperatures. With a snow cover, the ice temperature gradients in the topmost ice layers during cold weather were more typically of the order of -20 to $-5^{\circ} \mathrm{C} \mathrm{m}^{-1}$.

The flooding events of autumn 2003 almost doubled the thickness of the ice cover through the addition of snow ice at the top of the ice cover. Snow-ice layers were quickly added at the top of the ice cover as the slush froze quickly after flooding. Concurrently, congelation-ice growth at the bottom of the ice cover was negligible, and on occasion ceased because the ice was isothermal and near the freezing point. The ice-thickness data for this period at three ponds suggest that a small amount of ice might actually have melted off the bottom. There is a precedent for this in Antarctica, where flooding of the ice surface is common and the high oceanic heat flux leads to bottom melting as snow ice accretes at the top of the ice (e.g. Ackley and others, 1995; Lytle and Ackley, 1996). Since these are shallow ponds fed primarily by groundwater, often from point sources where springs upwell directly to the bottom of the ice, it is likely that there is a sufficiently high heat flux in the water to cause bottom melting when the ice temperatures are close to the freezing point. Holes, as large as $30-40 \mathrm{~cm}$ in diameter through the entire ice thickness $(28 \mathrm{~cm})$, observed on 29 November 2003 as the ice surface was flooding, suggest that the water upwelling below the ice had considerable heat content.

Flooding and snow-ice formation are common at these ponds and make an often significant contribution to the total ice thickness at the end of winter. Predictions based on computer models indicate that an increase in snowfall in central Alaska will lead to greater snow-ice formation that will comprise a larger proportion of the total ice thickness than congelation ice (Morris and others, 2005). An increase in flooding and snow-ice formation will likely lead to a warmer ice cover, and one that is more susceptible to bottom melting and loss of congelation ice.

The most extreme examples of isothermal ice near the freezing point occurred in association with high, sometimes briefly above-freezing, air temperatures and freezing rain in mid-February and early March 2003. Even with a snow cover $>20 \mathrm{~cm}$ deep, the entire ice thickness warmed rapidly as air temperatures increased, creating warm $(-0.5$ to $0^{\circ} \mathrm{C}$ ), chimney-like features in the ice temperature field. The ice subsequently cooled rapidly as air temperatures decreased after the warm, wet episodes, which lasted $<7$ days, i.e. the frequency of ice thickness measurements. While the ice was isothermal and warm, it is likely that there was a brief cessation of congelation-ice growth at the bottom of the ice cover, and perhaps even some bottom melting. These warming and cooling episodes were so rapid that the ice-thickness measurements were not frequent enough to provide information about changes at the bottom of the ice. 
The rapid response of ice temperatures to air-temperature variability is a particular feature of these data. Because of the air-temperature variability and the occurrence of extreme events such as winter rainfall associated with brief thawing episodes, large ice-temperature fluctuations occurred and the ice did not progressively cool over the course of the winter. Currently, there are an average of 3-4 days per winter when air temperatures rise above $0^{\circ} \mathrm{C}$, but climate change predictions for central Alaska suggest that winter thawing episodes might increase to $6-8$ per winter by the end of the 21 st century (personal communication from J. Walsh, 2004). Coupled with a greater amount of flooding (from below) and snow-ice formation, an increase in winter thawing and rainfall events is likely to lead to (1) higher average ice temperatures and more frequent occurrence of isothermal ice near the freezing point, and (2) further snow-ice formation resulting from the freezing of rain-flooded snow. Congelation-ice growth at the bottom of the ice cover is likely to be interrupted, perhaps even reversed by melting, more often. The processes described in this paper might be a glimpse of the future for lake ice thermal regimes and mass balance in central Alaska.

\section{ACKNOWLEDGEMENTS}

This work was supported by US National Science Foundation grant OPP 0117645. We thank K. Morris, L. Yocum and J. Watson for their essential help with the weekly snow and ice measurements. S. Fowell and P. McCarthy commented on early drafts of the manuscript.

\section{REFERENCES}

Ackley, S.F., V.I. Lytle, G.A. Kuehn, K.M. Golden and M.N. Darling. 1995. Sea-ice measurements during ANZFLUX. Antarct. J. U.S., 30(5), 133-135.

Adams, W.P. and T.D. Prowse. 1981. Evolution and magnitude of spatial patterns in the winter cover of temperate lakes. Fennia, 159(2), 343-359.

Adams, W.P. and N.T. Roulet. 1980. Illustration of the roles of snow in the evolution of the winter cover of a lake. Arctic, 33(1), 100-116.

Bengtsson, L. 1986. Spatial variability of lake ice covers. Geogr. Ann., 68A(1-2), 113-121.

Gow, A.J. and D. Langston. 1977. Growth history of lake ice in relation to its stratigraphic, crystalline and mechanical structure. CRREL Rep. 77-1.

Jones, J.A.A. 1969. The growth and significance of white ice at Knob Lake, Quebec. Can. Geogr., 13(4), 354-372.

Lytle, V.I. and S.F. Ackley. 1996. Heat flux through sea ice in the western Weddell Sea: convective and conductive transfer processes. J. Geophys. Res., 101(C4), 8853-8868.

Morris, K., M.O. Jeffries and C. Duguay. 2005. Model simulation of the effect of climate variability and change on lake ice in central Alaska, USA. Ann. Glaciol., 40 (see paper in this volume).

Perovich, D.K. and B.C. Elder. 2001. Temporal evolution of Arctic sea-ice temperature. Ann. Glaciol., 33, 207-211.

Ramseier, R.O. and R.J. Weaver. 1975. Floating ice thickness and structure determination - heated wire technique. Ottawa, Ont., Environment Canada. Inland Waters Directorate. Water Resources Branch. (IWD Tech. Bull. 88.)

Sturm, M., J. Holmgren, M. König and K. Morris. 1997. The thermal conductivity of seasonal snow. J. Glaciol., 43(143), 26-41 